This is a self-archived - parallel published version of this article in the publication archive of the University of Vaasa. It might differ from the original.

\title{
Cyclicality of Bank Liquidity Creation
}

Author(s): Davydov, Denis; Fungáčová, Zuzana; Weill, Laurent

Title: $\quad$ Cyclicality of Bank Liquidity Creation

Year: $\quad 2018$

Version: Accepted manuscript

Copyright Elsevier, Creative Commons Attribution Non-Commercial No Derivatives License

Please cite the original version:

Davydov, D., Fungáčová, Z., \& Weill, L., (2018). Cyclicality of Bank Liquidity Creation. Journal of international financial markets, institutions and money Vol(number), pp-pp. https://doi.org/10.1007/s11628-018-0361-1 


\title{
Cyclicality of Bank Liquidity Creation*
}

\author{
Denis Davydov ${ }^{1}$ \\ University of Vaasa \\ Zuzana Fungáčová2 \\ Bank of Finland \\ Laurent Weill ${ }^{3}$ \\ EM Strasbourg Business School, University of Strasbourg \\ Draft version: January 2018
}

\begin{abstract}
This paper investigates the cyclicality of bank liquidity creation. Since liquidity creation is a major economic function of banks, their liquidity creation behavior may amplify business cycle fluctuations. Using the methodology of Berger and Bouwman (2009) to compute liquidity creation measures, we analyze the relation between GDP growth and liquidity creation of Russian banks from 2004 to 2015. Detailed quarterly data on a very large sample of banks and coexistence of different bank ownership types (state-owned, domestic private and foreign banks), makes Russia an ideal natural laboratory for study of cyclicality of liquidity creation for banks. We find that liquidity creation of banks is procyclical. We show that the liquidity creation behavior of state-owned banks and foreign-owned banks is similar to that of domestic private banks in terms of procyclicality. We further find that the magnitude of procyclicality is higher for liquidity creation than for lending. Thus, while ownership of banks does not influence the cyclicality of bank liquidity creation, liquidity creation behavior of banks can amplify business cycle fluctuations.
\end{abstract}

JEL Codes: G21.

Keywords: bank, liquidity creation, business cycles, state ownership.

\footnotetext{
${ }^{1}$ School of Accounting and Finance, University of Vaasa, P.O. Box 700, FI-65101 Vaasa, Finland. Email: denis.davydov@uva.fi

${ }^{2}$ Bank of Finland Institute for Economies in Transition (BOFIT), Snellmaninaukio, P.O. Box 160, FI00101 Helsinki. Email: zuzana.fungacova@bof.fi

${ }^{3}$ Corresponding author. Institut d'Etudes Politiques, Université de Strasbourg, 47 avenue de la Forêt Noire, 67082 Strasbourg Cedex. Phone: +33-3-68-85-81-38. Email: laurent.weill@unistra.fr

* We thank Allen Berger, Iikka Korhonen, Sergey Mityakov, Anna Pestova, Alexey Porshakov, Alberto Pozzolo, Laura Solanko, the participants of the $6^{\text {th }}$ CInst Banking Workshop (Moscow, October 2016), 14 ${ }^{\text {th }}$ Workshop on Emerging Markets (Madrid, November 2016), ${ }^{\text {th }}$ Informal Russia Workshop (Frankfurt, November 2016), 57 $7^{\text {th }}$ Annual Conference of the Southern Finance Association (Key West, November 2017), 26 ${ }^{\text {th }}$ International Rome Conference on Money, Banking and Finance (Palermo, December 2017), the research seminars at the University of Vaasa (October 2016), University of Stockholm (February 2017) and at the Bank of Finland Institute for Economies in Transition (February 2017) for their valuable comments and suggestions. Denis Davydov also gratefully acknowledges the financial support from the Finnish Foundation for Economic Education.
} 


\section{Introduction}

Liquidity creation is a major function of banks in the economy. Banks create liquidity by financing relatively illiquid assets with relatively liquid liabilities and thus contribute to financing the economy and facilitating transactions between economic agents. It is generally accepted that liquidity creation favors economic growth (e.g. Berger and Sedunov, 2017; Fidrmuc, Fungáčová and Weill, 2015).

The literature on bank liquidity creation saw a recent boost with the novel approach proposed by Berger and Bouwman (2009) to measure liquidity created by banks. Several works build on this approach in examining the determinants of liquidity creation (e.g. Berger, Bouwman, Kick, and Schaeck, 2016; Fungáčová, Weill, and Zhou, 2017), as well as the consequences of liquidity creation for financial stability (Berger and Bouwman, 2017; Fungáčová, Turk, and Weill, 2015).

The aim of this paper is to investigate cyclicality of bank liquidity creation. Berger and Bouwman (2015) point out that bank lending alone is not an optimal measure of bank output. In order to account for differences in loan categories and composition on the liability side, one should rather look at the bank liquidity creation. Even as cyclicality of bank lending has received attention (e.g. Micco and Panizza, 2006; Bertay, DemirgüçKunt, and Huizinga, 2015), no studies to the best of our knowledge consider how bank core output in the form of liquidity creation reacts to business cycle fluctuations. Given the key function of banks as liquidity creators, cyclicality of bank liquidity creation might generate undesirable effects in the economy by amplifying recessions. From a theoretical perspective, we can expect that liquidity creation is cyclical since liquidity creation overall increases with greater lending and deposit activities of banks. Since there is former evidence on cyclicality for lending and since GDP growth is likely to be positively correlated with deposit growth, the liquidity creation is likely to be cyclical. However, liquidity creation is a broad measure of bank output taking into account e.g. the differences between categories of loans. It is therefore necessary to check if empirical evidence is in line with this expectation.

This study also considers whether liquidity creation by state-owned banks might be less procyclical than liquidity creation of domestic private banks and foreign banks. Such 
a finding would imply that state-owned banks play a greater role in economic stabilization than domestic private banks or foreign banks. Bertay, Demirgüc-Kunt and Huizinga (2015) perform a cross-country analysis to investigate whether cyclicality of lending differs for state-owned banks relative to private banks and show that lending of state-owned banks tends to be less procyclical than lending of private banks. Thus, we ask if this finding holds for the broader notion of liquidity creation as well.

To investigate these issues, we follow the methodology of Berger and Bouwman (2009) in measuring bank liquidity creation. We classify all bank assets and liabilities based on their degree of liquidity, then assign weights to each item and compute the amount of liquidity created by each bank. We consider the Russian banking system for our analysis and use comprehensive quarterly data from financial reports of the Russian banks covering the period 2004-2015. The availability of a rich panel dataset on all Russian banks in terms of level of detail and frequency allows for the measurement of liquidity creation and for the investigation of business cycle fluctuations. The coexistence of state-owned, domestic private and foreign banks - especially with each type of bank controlling significant market shares - makes Russia an ideal natural laboratory for analyzing how ownership influences cyclicality of bank liquidity creation.

The Russian banking system has largely expanded with a credit to GDP ratio rising from $22.8 \%$ in 2004 to $52.8 \%$ in 2015 . $^{1}$ The ratio of bank credit to bank deposits is $110.31 \%$ in 2015 , meaning that loans are funded by deposits at the aggregate level. The Russian banking industry includes a very large number of banks even if the number of banks has massively decreased in the recent years with a fall from 1,299 in 2009 to 733 in 2015 and below 570 in 2017 . However the banking market is highly concentrated with the five largest banks controlling $54.1 \%$ of the market in 2015. Largest banks are stateowned banks. According to Vernikov (2017) for 2015, Russian banking market includes 41 state-owned banks including the largest ones and 61 foreign banks, while all other institutions are small domestic private banks. It is of interest to stress that state-owned banks create more liquidity than other banks (Fungacova and Weill, 2012).

This paper contributes to the literature on bank liquidity creation by providing evidence on its cyclical nature and potential amplifying role in economic recessions. It

\footnotetext{
${ }^{1}$ All figures come from the Central Bank of Russia.
} 
also relates to the discussion on the economic impact of state ownership of banks. This is particularly relevant to emerging economies, where banks typically play a major financing role and the state may be heavily involved in the banking industry.

The rest of the article is structured as follows. Section 2 reviews the related literature. Section 3 presents data and methodology. Section 4 displays the main estimations. Section 5 provides additional estimations on cyclicality of bank lending. Section 6 concludes.

\section{Related literature}

Our paper relates to two strands of literature. The first deals with bank ownership and lending behavior, the second with bank liquidity creation.

Regarding the first strand, many studies note the strong association between bank ownership and lending behavior. Consistent with the political view of state ownership, some of these studies show that state-owned banks can be exploited by politicians in ways that drive bank lending to suboptimal levels, especially around electoral periods (Sapienza, 2004; Dinç, 2005; Khwaja and Mian, 2005; Carvalho, 2014; Infante and Piazza, 2014).

On the other hand, some researchers find, especially after the credit crunch of 2008 , that state ownership of banks can be quite valuable in providing a semblance of economic stability in times of financial turmoil. State-owned banks can increase their lending during crises even as foreign banks pull back sharply (Brei and Schclarek, 2013, for a worldwide sample; Fungáčová, Herrala, and Weill, 2013, for Russia; Albertazzi and Bottero, 2014, for Italy; De Haas et al., 2015, for Eastern Europe).

Many studies tackle state ownership of banks and its impact on lending (Cull and Martinez Peria, 2013, for Latin and Eastern Europe; Davydov, 2018, for Russia).

Despite this wide-ranging body of literature, there has been little discussion on how various types of banks react to business cycle fluctuations. Linking credit and GDP growth, Micco and Panizza (2006) find that lending by state-owned banks is less cyclical than lending by privately owned banks on an international sample of banks. Using an 
extensive dataset from 111 countries during 1999-2010, Bertay, Demirgüc-Kunt and Huizinga (2015) show that state-owned banks lend countercyclically regardless of financial crises. While these results are especially strong for developed countries with good governance, their general conclusion is that state involvement through government ownership of banks serves as a stabilizing force throughout the business cycle.

Duprey (2015) confirms these findings with bank data from 83 countries over the period 1990-2010. He documents that privatized banks are associated with increased lending cyclicality by combining state ownership with individual privatization/nationalization events.

Behr, Foos, and Norden (2017) examine the effect of government involvement in banks on cyclicality of lending to small and medium-sized enterprises. Using Germany's unique institutional setting, they show that state involvement in a bank reduces the sensitivity of bank lending to GDP growth. On average, lending by banks with state involvement is $25 \%$ less cyclical than for other types of local banks.

The second strand of literature involves the emerging topic of bank liquidity creation. A key motivation for the focus on the function of banks as liquidity creators is the argument from Berger and Bouwman (2015) that bank lending alone is not an optimal measure of bank output. In order to account for differences in loan categories and composition on the liability side, one should rather look at the bank liquidity creation measure suggested by Berger and Bouwman (2009).

Berger and Bouwman (2009) propose an operational procedure to measure bank liquidity creation. Before their work, we are only aware of one work proposing a measure of bank liquidity creation: Deep and Schaefer (2004). This paper considers the ratio of the difference between liquid liabilities and liquid assets scaled by total assets to measure liquidity creation. It is therefore a very gross measure which does not take into account the whole classification of assets and liabilities.

Berger and Bouwman (2009) provide a three-step procedure based on the classification of all bank balance sheet items in terms of liquidity, the assignment of weights to these items, and the application of a formula. They consequently provide a comprehensive and operational approach to measure bank liquidity creation which is the natural measure to adopt in our work on cyclicality of bank liquidity creation. 
They implement their approach on US banks from 1993 to 2003. They find that liquidity creation in the US has substantially increased during that period. They also identify several determinants of liquidity creation including large banks and bank involved in merger activity. Finally, they observe that the relationship between capital and liquidity creation is positive for large banks but negative for small banks.

Existing empirical literature in the emerging research area of bank liquidity creation focuses on determinants of bank liquidity creation. Several studies suggest, for example, that while bank capital tends to be negatively related to liquidity creation, it may depend on bank size and presence of deposit insurance system (Lei and Song, 2013; Fungáčová, Weill, and Zhou, 2017). This relationship can even be reversed, implying that greater liquidity creation increases the probability of bank failure (Fungáčová, Turk, and Weill, 2015). At the same time, liquidity creation by banks may be sensitive to regulatory interventions and bailouts (Berger et al., 2016) or to monetary policy (Rauch et al., 2011). For the latter category, the sensitivity may depend on bank size and general economic conditions (Berger and Bouwman, 2017).

The existing literature suggests that bank ownership may be a major determinant of bank liquidity creation. Fungáčová and Weill (2012) provide the first investigation of bank liquidity creation in Russia. They provide measures of liquidity creation for Russian banks from 1999 to 2009. They show that liquidity creation volume is much lower in Russia than in the US. However, liquidity creation ratios, which relate liquidity creation to total assets, are of the same order of magnitude in both countries. Hence, they conclude that Russian banks are not particularly reluctant to perform their liquidity-creation functions. They document that large state-owned banks have the greatest impact on liquidity creation in Russia and also point out that liquidity creation has strongly increased between 1999 and 2009. Moreover, while on average liquidity creation by private domestic and foreign banks contracted during the recent financial crisis, stateowned banks did not reduce their liquidity creation. These results could also indicate potential countercyclical behavior in liquidity creation by state-controlled banks.

Lei and Song (2013) argue that general negative relation between bank capital and liquidity creation is irrelevant for foreign banks operating in China. Their findings underline the importance of type of bank ownership and its impact on liquidity creation. 
Several recent studies show that liquidity creation by banks positively affects economic growth. Berger and Sedunov (2017) argue that higher levels of bank liquidity creation are associated with significantly higher GDP in individual US states. Fidrmuc, Fungáčová, and Weill (2015) document that liquidity creation by banks is positively related to economic growth in Russian regions (a relationship that held even during the recent financial crisis).

Overall, these results imply that development of the financial sector may significantly contribute to economic growth through the bank liquidity creation channel.

\section{Data and methodology}

\subsection{Data description}

We employ quarterly bank-level financial statement data for Russian banks from the Central Bank of Russia (CBR). The period covered is 2004-2015. The dataset contains detailed information that is necessary for calculation of the bank liquidity creation measures. We distinguish among corporate, household, and government loans, as well as types of deposits. Our data also contains detailed information on maturity of various balance sheet items. Since the data cover all Russian banks, there is no selection bias.

We augment our original dataset with additional data on state ownership of banks from Vernikov (2017) and define a bank as state-owned if the majority stake in the bank is held by the federal government, central bank, state-owned enterprises, regional government, or municipality. We define foreign banks as those where foreign owners hold more than $50 \%$ of the bank's equity. The data on foreign ownership are obtained from the CBR, www.allbanks.ru webpage and the banks' own websites. We also consider macro-level variables provided by Russia's Federal State Statistics Service (Rosstat).

By excluding non-bank organizations from our sample, we ensure that the data only include commercial banks. We trim our dependent variables at the $2.5 \%$ and $97.5 \%$ to avoid extreme outliers. The final sample consists of unbalanced panel observations on 1,180 individual banks. Depending on the model specification, the number of 
observations varies between 33,099 and 35,349 bank-quarter observations. Descriptive statistics of the variables used in our analysis are provided in Table 1.

\subsection{Liquidity creation measures}

Taking Russia-specific factors into account, we construct our bank liquidity creation measures using the three-step procedure developed by Berger and Bouwman (2009). In the first step, we classify all bank balance sheet items as liquid, semi-liquid, or illiquid. This classification is based on the ease, cost, and time necessary for banks (customers) to turn their obligations into liquid funds (withdraw funds).

Next, we assign weights to all balance sheet items. Following the theory of financial intermediation, banks are seen to create liquidity by transforming illiquid assets to liquid liabilities. We thus apply positive weights to these two balance sheet categories. One unit face value of liquidity is created when a unit of liquid liabilities (e.g. current account deposits, weighted 0.5) is used to finance a unit of illiquid assets (e.g. corporate loans, weighted 0.5). We assign negative weights to liquid assets, illiquid liabilities and capital. One unit of liquidity is destroyed when one unit of illiquid liabilities or equity is used to finance a unit of liquid assets (e.g. government securities).

Equation (1) presents the functional form used to construct the bank liquidity creation measures in the third step.

Liquidity Creation $=\left\{1 \frac{1}{2} \times\right.$ Illiquid Assets $+0 \times$ Semi-Liquid Assets $-1 / 2 \times$ Liquid Assets $\}$ $+\{1 / 2 \times$ Liquid Liabilities $+0 \times$ Semi-Liquid Liabilities $-1 / 2 \times$ Illiquid Liabilities $\}-1 / 2 \times$ Capital

In line with Berger and Bouwman (2009), we construct two measures of liquidity creation from Equation (1) using two definitions for each of the right-hand-side terms. The classification of balance sheet items is based on category for the first measure and on maturity of the individual balance sheet items for the second measure. Table 2 provides a detailed description of balance sheet items used to calculate these two liquidity creation measures and the weights assigned to each group. 
Our benchmark liquidity creation measure is based on the classification of balance sheet items by category. Liquid assets include cash, accounts with banks, and total securities (stocks, debt securities, and promissory notes). Customer loans are divided into corporate loans, loans to individuals, and loans to government. Since banks generally lack the option of selling corporate loans to meet their liquidity needs, such loans are considered illiquid assets. Other categories of loans, including loans to individuals, loans to the government and interbank loans, are classified as semi-liquid assets. As mortgage lending is a recent phenomenon in Russia, most loans to individuals are short-term loans for buying consumer goods. We treat these loans as semi-liquid, because items with shorter maturity tend to be more liquid than longer-term items, notwithstanding rare loan securitization in Russia. The illiquid assets category includes other assets containing e.g. tangible and intangible assets.

On the liability side, we distinguish between three broad categories: claims of banks, claims of the non-banking sector, and debt securities issued by banks. Claims of banks are readily available for withdrawal and fall into the liquid liabilities category. In contrast, there are two types of claims of the non-banking sector. The first category includes the settlement accounts of clients (domestic and foreign firms, government, and households). These are classified as liquid liabilities. Customers can easily withdraw these funds without penalty. The second category of claims of non-banking sector contains term deposits classified as semi-liquid liabilities. These may be difficult or costly to withdraw immediately. The debt securities issued by banks belong either to the liquid category (promissory notes and bonds) or the semi-liquid category (deposit and saving certificates). This categorization is based on the liquidity of these instruments in Russia. The illiquid liabilities category consists of other liabilities that we calculate as the difference between total liabilities and the sum of all the above-mentioned claims. We include bank capital here.

The alternative liquidity creation measure that we use in our analysis is based on the classification of balance sheet items by maturity. To calculate this measure, we redefine the subgroups of balance sheet items. Liquid assets are defined in the same way as it was the case for classification by category. Semi-liquid assets consist of various types of loans with maturity of less than one year. The illiquid assets category contains 
loans with maturity over a year, loans of unknown maturity and other assets (e.g. tangible and intangible assets). Liquid liabilities include settlement accounts, claims of banks and debt securities issued (bonds and promissory notes). Semi-liquid liabilities contain all deposits with maturity less than one year and debt securities issued (deposit and saving certificates). Illiquid liabilities consist of deposits with maturity of more than a year, undefined maturity, and other liabilities. As with our benchmark measure of liquidity creation based on category classification, we treat bank capital as an illiquid balance sheet item.

In line with Berger and Bouwman (2009), our category-based liquidity creation measure is the benchmark indicator. While these authors developed the methodologies for computing both measures, they themselves prefer the category-based measure. In their view: "What matters to liquidity creation on the asset side is the ease, cost, and time for banks to dispose of their obligations to obtain liquid funds. The ability to securitize loans is closer to this concept than the time until self-liquidation." (Berger and Bouwman, 2009, p. 3797).

We present statistics for the variation in our two main variables - the categorybased liquidity creation measure and credit growth by bank type in Panel B of Table 1. While the variation in liquidity creation is higher for foreign banks than for domestic private banks and for state-owned banks, we find that the differences are not statistically significant. However, credit growth is significantly higher for foreign banks than for the other two bank types. It is also significantly higher for domestic private banks than for state-owned banks. In additional tests (not tabulated), we have also investigated if liquidity creation growth and credit growth were influenced by the global financial crisis. Both were negatively impacted by the crisis and increased after that without reaching the pre-crisis levels. 


\subsection{Methodology}

We begin our empirical analysis of cyclicality of liquidity creation with two-way fixed effects estimations ${ }^{2}$. We estimate different specifications of the following model:

$$
\begin{gathered}
\Delta L I Q_{i, t}=\alpha_{i}+\beta_{1} \Delta M_{i}+\beta_{2} O W N_{i, t}+\beta_{3} \Delta M_{i} * O W N_{i, t}+\beta_{z} X_{i, t-1} \\
\quad+B A N K_{i}+T I M E_{t}+\varepsilon_{i, t}
\end{gathered}
$$

where, $\Delta L I Q_{i, t}$ is the change in liquidity creation by bank $i$ in quarter $t$ and $\Delta M_{i}$ is the change in the macroeconomic indicator for business cycle. We utilize alternatively two indicators for business cycles. GDP per capita growth is used in the main estimations in line with earlier papers (e.g., Bertay et al. 2015). We adopt real investment growth in the robustness check as an alternative indicator. To avoid seasonal fluctuations in the quarterly liquidity creation and macroeconomic variables, we calculate the change by dividing quarterly observations in year $t$ by the same quarter in year $t-1$.

To examine the effect of bank ownership characteristics, we include $O W N_{i, t}$, a vector of dummy variables for state, foreign, and private domestic ownership. We also include interaction terms of macro variables and ownership dummies to examine the differential effect of macroeconomic fluctuations on liquidity creation between stateowned, foreign, and private banks. $X_{i, t-1}$ is a matrix of bank-specific control variables. Following the related literature on cyclicality of lending (Bertay, Demirgüc-Kunt and Huizinga, 2015) and on bank liquidity creation (Berger and Bouwman, 2009), we include lagged values of bank size (log of total assets), the equity-to-assets ratio, the nonperforming-loans-to-total-loans ratio, and the total-loans-to-total-assets ratio as control variables. $B A N K_{i}$ and $T I M E_{t}$ are the bank and time fixed effects. $\varepsilon_{i, t}$ is an error term.

Our baseline regression model with fixed effects is potentially a subject to endogeneity problem since we can have reverse causality from growth in liquidity creation to GDP per capita growth. To tackle this problem and account for the dynamic

\footnotetext{
${ }^{2}$ We perform a Hausman (1978) specification test to identify whether individual-level effects can be captured in random-effects models. The unreported test clearly rejects the random-effects assumptions and confirms the choice of fixed-effects estimations as preferred specification.
} 
properties of our panel, we include a lagged dependent variable to the right-hand-side of the equation and apply a dynamic two-step system GMM estimator (Arellano and Bover, 1995; Blundell and Bond, 1998) using differenced variables as instruments. We assume that our macroeconomic and ownership variables together with interaction terms are predetermined, implying that they are not correlated with future error terms. All other bank-specific controls are considered as endogenous and instrumented with their lags.

This approach leads to a relatively high number of instruments. To avoid an overidentification problem, we use the collapse option suggested by Roodman (2009) for bank-specific control variables and limit the number of lags used as other instruments accordingly. We apply the Windmeijer (2005) correction for standard errors and test for the autocorrelation in residuals with Arellano-Bond test. We report Hansen test for overidentifying restrictions where the null hypothesis is that the instruments used are appropriate.

\section{Results}

This section presents the results on cyclicality of bank liquidity creation in Russia. We report the main estimations before testing the sensitivity of the results with robustness checks.

\subsection{Main estimations}

Table 3 presents the main estimations. In columns 1 and 2, we report results without ownership variables. These variables are included in columns 3 and 4 . In each case, we perform estimations alternatively with panel fixed effects and system GMM estimators to check the sensitivity of our results. Several conclusions emerge.

First, GDP per capita growth enters with positive and significant coefficients in all regressions. Based on specification 1, we infer that an increase of 1 percentage point in GDP per capita growth contributes to a 0.711-point increase in bank liquidity creation. Liquidity creation behavior of banks is thus procyclical, i.e. banks create liquidity in boom times and reduce liquidity creation during bust times. This finding is important as 
liquidity creation ostensibly exerts beneficial effects on economic activity (Fidrmuc, Fungáčová, and Weill, 2015; Berger and Sedunov, 2017). In other words, the liquidity creation behavior of banks can amplify the business cycle.

Second, the interactions of GDP growth with ownership dummies are not significant. These results imply the absence of difference in cyclicality of liquidity creation by bank ownership. In other words, the liquidity creation behavior of stateowned banks and foreign banks is not different from domestic private banks in terms of procyclicality. The ownership dummies are also not significant, suggesting no difference in liquidity creation behavior over the period between different types of ownership.

Our results differ from those observed on cyclicality of bank lending in Bertay Demirgüc-Kunt and Huizinga (2015). First, our results concern liquidity creation, a broader concept than bank lending. Second, our observations are exclusive to Russia, while the analysis of Bertay, Demirgüc-Kunt and Huizinga (2015) is based on a crosscountry sample of 111 countries. Third, we depart from the conclusion of Fungáčová, Herrala, and Weill (2013) that foreign banks tend to reduce their credit supply more and state-owned banks less than domestic private banks in Russia. But again, their findings consider credit supply in isolation, not liquidity creation - and their study is limited to a period of financial crisis.

Overall, our findings on the cyclicality of liquidity creation and the role of bank ownership show a pattern unlike that observed for bank lending alone. They support the thesis that examining liquidity creation provides additional information for assessing how bank behavior may amplify business cycles.

We now turn to the analysis of control variables. We observe a negative and significant sign for equity to assets, suggesting that more capitalized banks have lower liquidity creation growth. This result is in line with Behr, Foos and Norden (2017) who find that more capitalized banks have lower loan growth, while Bertay, Demirgüc-Kunt and Huizinga (2015) obtain no significant link. The ratio of loans to total assets is significantly positive, indicating that a greater share of loans in the balance sheet is associated with greater liquidity creation growth. This finding contrasts with the negative coefficient obtained by Bertay, Demirgüc-Kunt and Huizinga (2015) but our study differs from theirs by focusing on liquidity creation. The share of overdue loans in loans is 
significantly negative, supporting the view that banks with lower quality of their loan portfolio slow down liquidity creation. Finally, bank size is not significant in most specifications, suggesting that size does not influence liquidity creation growth.

A natural question emerges if cyclicality of liquidity creation is symmetric for ownership types. Namely, the findings on cyclicality of liquidity creation by ownership type can be asymmetric. The average result can be driven by different liquidity creation behaviors at different stages of the business cycle. For instance, if state-owned banks create more liquidity in both bust and boom times than domestic private banks, the average would be that state-owned banks are no more or less procyclical in their behavior than domestic private banks, i.e. they are more procyclical in boom times and less procyclical in bust times. Yet there is no doubt that their behavior differs from that of the domestic private banks with respect to business cycle fluctuations.

To investigate this question, we replace GDP growth by two variables: High GDP growth and Low GDP growth. Following the approach of Behr et al. (2017), we use the value of average GDP per capita growth during the sample period to distinguish periods of high and low growth. In periods of high growth, the High GDP growth variable is equal to the actual GDP per capita growth if the value is above average, and zero otherwise. Correspondingly, in periods of low growth, Low GDP Growth is equal to the actual GDP per capita growth if the value is below average, and zero otherwise. This approach enables us to investigate if cyclicality in bank liquidity creation is symmetric through the whole business cycle or asymmetric by only occurring in certain stages of the business cycle. ${ }^{3}$ Table 4 reports the estimations.

We observe that estimated coefficient for High GDP growth is significantly positive, while the coefficient for Low GDP growth is significantly negative. Not tabulated F-tests indicate that coefficients on High GDP growth and Low GDP growth are statistically different from zero $(\mathrm{F}-\mathrm{stat}=24.47)$ and reject the hypothesis on equality of these coefficients at the $1 \%$ level $(\mathrm{F}$-stat $=43.32)$. This finding confirms that the conclusion on procyclical liquidity creation for all banks is observed in both bust and

\footnotetext{
${ }^{3}$ We have also performed estimations for different sub-periods to check whether cyclicality of bank liquidity creation has changed before and after the global financial crisis. We do not observe any change for cyclicality concerning the different types of banks and therefore do not report these estimates for the sake of brevity.
} 
boom times. Hence, procyclicality of liquidity creation is not driven by a particular stage of the business cycle. The magnitude of the coefficients for High GDP growth and Low GDP growth indicates, however, that economic downturns may have a marginally stronger impact on the change in liquidity creation than upturns. One standard deviation change in Low GDP growth causes a change in liquidity creation of 0.04 , while a similar change in High GDP growth leads to 0.03-point change.

Interaction terms between ownership dummies and GDP growth are not significant. Therefore, there is no asymmetry in the cyclicality of liquidity creation for state-owned banks or foreign banks. These banks do not react any differently to booms or busts than domestic private banks.

\subsection{Robustness checks}

While the two estimation approaches (fixed effects and system GMM) applied in the main estimations already provide a robustness check of our results, we nevertheless check the robustness of our findings with three additional estimations. First, we use an alternative measure for liquidity creation. We have used the category-based liquidity creation measure in our main estimations. We can, however, see if our main findings remain valid when liquidity creation is measured through classification of balance sheet items based on maturity rather than category. We repeat our regressions with the maturity-based liquidity creation measure and report the findings in Table 5.

Our results with the maturity-based liquidity creation measure corroborate the main findings obtained with the category-based liquidity creation measure. We again observe a positive coefficient for GDP growth in all regressions. It is significant in three of the four specifications supporting our conclusion that liquidity creation is procyclical. We still find no significance for interaction terms between ownership dummies and GDP growth. This finding confirms that cyclicality of liquidity creation does not differ across types of banks. To sum up, the estimations with the maturity-based liquidity creation measure confirm main findings obtained with the category-based liquidity creation measure.

A different result emerges when it comes to ownership dummy variables. While they were not significant when the category-based liquidity creation measure was 
considered, we now see positive and significant coefficients for State-owned and Foreign dummy variables in the system GMM regression. These results support the view that state-owned banks and foreign banks increased liquidity creation more over the period than domestic private banks. They are, however, only observed in the system GMM regression and not confirmed by the panel regression with fixed effects.

Second, we use an alternative indicator for the business cycle. One could argue that GDP per capita growth does not fully reflect the state of the Russian economy. We redo our estimations by utilizing real investment growth as the indicator of the business cycle. Table 6 displays these estimations.

The coefficient for real investment growth is significantly positive, supporting the finding of procyclical liquidity creation behavior. We again find no difference when considering the behavior of state-owned and foreign banks. Interaction variables between ownership dummies and real investment growth are not significant.

Thus, the estimations with the alternative business cycle indicator confirm our findings on procyclicality of liquidity creation for all banks, and no differences across bank ownership types.

Third, we investigate whether the cyclicality of liquidity creation differs with size of banks. Studies on liquidity creation show significant differences in liquidity creation of banks depending on size (Berger and Bouwman, 2009). It is therefore of interest to check if size matters for our main finding of procyclicality of liquidity creation.

We consider three size classes of banks based on their ranking by total assets. Large banks are the top 50 banks by total assets, medium banks the next 150 banks, and small banks all others ${ }^{4}$. Table 7 reports the estimations for each size class. As our previous estimations have shown that regressions with fixed effects and with system GMM provide very similar results, we only display the estimations with fixed effects for the sake of brevity. We find that GDP growth is significantly positive for all size classes, while interaction terms between GDP growth and ownership dummies are not significant. Hence, these results corroborate our main findings on procyclicality of liquidity creation

\footnotetext{
${ }^{4}$ This division reflects the structure of the Russian banking sector. Despite a high number of banks, most are small and only operate at the local or regional level. We get the same results with alternative groupings that consist of Russia's top 25 banks, the 100 next-largest banks, and all other banks.
} 
for all banks, and on the absence of differences in cyclicality for ownership types of banks.

\section{Cyclicality of liquidity creation vs. cyclicality of lending}

Our investigation on cyclicality of liquidity creation in the case of Russian banks so far has established two key findings: 1) the existence of procyclicality of liquidity creation, and 2) a lack of significant differences among the three bank ownership types with respect to procyclicality of liquidity creation.

We now ask if these findings are valid for bank lending. Bank liquidity creation is a broad measure of bank output that includes bank lending, but also other types of assets. It also takes the liability structure into consideration. Thus, liquidity creation and bank lending may not necessarily exhibit the same cyclical behavior. Moreover, cyclicality of ownership types may even differ between bank liquidity creation and bank lending, i.e. different types of banks may have different behaviors for items other than loans.

We now perform our estimations by considering a new dependent variable: the growth rate of total loans. This is the same variable that Bertay, Demirgüc-Kunt and Huizinga (2015) and Behr, Foos and Norden (2017) consider in their analysis of the cyclicality of bank lending.

Table 8 reports the estimations for cyclicality of bank lending. Again, since regressions with fixed effects and system GMM provide similar results in the main estimations, we only display the estimations with fixed effects for the sake of brevity. In column 1, we consider GDP per capita growth. In column 2, we include the interaction terms between GDP per capita growth and ownership dummies. In column 3, we consider the possible asymmetric lending behavior of different types of banks.

First, we observe that bank lending is procyclical with a significantly positive coefficient for GDP growth in the first two columns. Hence, bank lending is also procyclical. To assess the magnitude of this procyclicality we compare regressions 1 in Table 3 (for liquidity creation) and Table 8 (for lending) and observe that one standard deviation increase in GDP per capita growth causes a 0.08-point increase in bank 
liquidity creation but only a 0.05 -point increase in lending. In other words, liquidity creation is more procyclical than lending. Furthermore, High GDP growth is significantly positive and Low GDP growth is significantly negative in column 3. These results show the positive relation between GDP growth and bank lending observed in booms and busts.

Second, we find evidence for a different pattern for state-owned and foreign banks compared to domestic private banks. In column 2, the interaction of GDP growth with Foreign is significantly positive, suggesting that foreign banks have a greater cyclicality of bank lending than domestic private banks. In column 3, we observe that Foreign $\times$ High GDP growth is significantly positive, while Foreign $\times$ Low GDP growth is not significant. In booms, foreign banks amplify the expansion by increasing bank lending more than domestic private banks. However they reduce their lending similarly when the business cycle turns to bust.

Finally, for state-owned banks, we observe no significant coefficient for the interaction of GDP growth with State-owned in column 2. However, when we examine the possibility of asymmetric lending behavior in column 3, we find a significantly positive coefficient for State-owned $\times$ Low GDP growth but no significant coefficient for State-owned $\times$ High GDP growth. This suggests that state-owned banks increase their lending more than domestic private banks during busts, and comports with the view that the lending behavior of state-owned banks is less procyclical. It also corroborates the observations of Bertay, Demirgüc-Kunt and Huizinga (2015) at the world level and Fungáčová, Herrala and Weill (2013) for Russia.

Overall, the estimations for cyclicality of lending show similarities and differences with those for cyclicality of liquidity creation. We find evidence of procyclicality for all banks in both sets of estimations, with some differences by ownership type. For lending only, we find evidence that foreign banks are more procyclical and state-owned banks less procyclical than domestic private banks. 


\section{Conclusions}

This study examined cyclicality of bank liquidity creation. While liquidity creation is a major function of banks in the economy, no paper to date has posed the question of whether liquidity creation is procyclical and thereby might amplify business cycle fluctuations. We analyze this question on the Russian banking system by taking into account potential differences across various bank types. As the literature contains evidence that lending of state-owned banks may be less cyclical than other banks, we also check to see if a similar result is observed for liquidity creation.

Our findings can be summarized as follows. First, we observe that liquidity creation of banks is procyclical, i.e. business cycle fluctuations are positively associated with bank liquidity creation. The magnitude of procyclicality is higher for liquidity creation than for lending. Second, we show that state-owned banks and foreign banks do not have a more or less procyclical liquidity creation behavior than domestic private banks.

These findings have several implications. Liquidity creation behavior of banks can contribute to amplify business cycle fluctuations since liquidity creation has been shown to exert beneficial effects on economic activity. Normatively, the evidence is neutral as to the effects of state ownership of banks. From a research perspective, however, we see liquidity creation broadens the concept of bank output beyond lending and offers tantalizing new avenues for further research. 


\section{References}

Albertazzi, U. and M. Bottero (2014). Foreign bank lending: Evidence from the global financial crisis. Journal of International Economics 92(S1), S22-S35.

Arellano, M. and O. Bover (1995). Another look at the instrumental-variable estimation of error-components. Journal of Econometrics 68, 29-52.

Behr, P., D. Foos, and L. Norden (2017). Cyclicality of SME lending and government involvement in banks. Journal of Banking and Finance 77, 64-77.

Berger, A. and C. Bouwman (2009). Bank liquidity creation. Review of Financial Studies 22(9), 3779-3837.

Berger, A. and C. Bouwman (2017). Bank liquidity creation, monetary policy, and financial crises. Journal of Financial Stability 30, 139-155.

Berger, A. and C. Bouwman (2015). Bank liquidity creation and financial crises. Academic Press, Elsevier.

Berger, A., C. Bouwman, T. Kick, and K. Schaeck (2016). Bank liquidity creation following regulatory interventions and capital support. Journal of Financial Intermediation 26, 115-141.

Berger, A. and J. Sedunov (2017). Bank liquidity creation and real economic output. Journal of Banking and Finance 81, 1-19.

Bertay, A., A. Demirgüç-Kunt, and H. Huizinga (2015). Bank ownership and credit over the business cycle: Is lending by state banks less procyclical? Journal of Banking and Finance 50, 326-339.

Blundell R. and S. Bond (1998). Initial conditions and moment restrictions in dynamic panel data models. Journal of Econometrics 87, 115-143.

Brei, M. and A. Schclarek (2013). Public bank lending in times of crisis. Journal of Financial Stability 9(4), 820-830.

Carvalho, D. (2014). The real effects of government-owned banks: Evidence from an emerging market. Journal of Finance 69(2), 577-609.

Cull, R. and M. Martinez Peria (2013). Bank ownership and lending patterns during the 2008-2009 financial crisis: Evidence from Latin America and Eastern Europe. Journal of Banking and Finance 37(12), 4861-4878.

Davydov, D. (2018). Does state ownership of banks matter? Russian evidence from the financial crisis. Journal of Emerging Market Finance (forthcoming).

De Haas, R., Y. Korniyenko, A. Pivovarsky, and T. Tsankova (2015). Taming the herd? Foreign banks, the Vienna initiative and crisis transmission. Journal of Financial Intermediation 24(3), 325-355.

Duprey, T. (2015). Do publicly owned banks lend against the wind? International Journal of Central Banking 11(2), 65-112.

Dinç, I. (2005). Politicians and banks: Political influences on government-owned banks in emerging markets. Journal of Financial Economics 77(2), 453-479. 
Fidrmuc, J., Z. Fungáčová, and L. Weill (2015). Does bank liquidity creation contribute to economic growth? Evidence from Russia. Open Economies Review 26(3), 479496.

Fungáčová, Z., R. Herrala, and L. Weill (2013). The influence of bank ownership on credit supply: Evidence from the recent financial crisis. Emerging Markets Review $15,136-147$.

Fungáčová, Z., R. Turk Ariss and L. Weill (2015). High liquidity creation and bank failures. International Monetary Fund Working Paper 15/103.

Fungáčová, Z. and L. Weill (2012). Bank liquidity creation in Russia. Eurasian Geography and Economics 53(2), 285-299.

Fungáčová, Z., L. Weill, and M. Zhou (2017). Bank capital, liquidity creation and deposit insurance. Journal of Financial Services Research 51(1), 97-123.

Infante, L. and M. Piazza (2014). Political connections and preferential lending at local level: Some evidence from the Italian credit market. Journal of Corporate Finance $29,246-262$.

Khwaja, A. and A. Mian (2005). Do lenders favor politically connected firms? Rent provision in an emerging financial market. Quarterly Journal of Economics 120(4), 1371-1411.

Lei, A. and Z. Song (2013). Liquidity creation and bank capital structure in China. Global Finance Journal 24(3), 188-202.

Micco, A. and U. Panizza (2006). Bank ownership and lending behavior. Economics Letters 93(2), 248-254.

Rauch, C., S. Steffen, A. Hackethal, and M. Tyrell (2011). Determinants of bank liquidity creation. Working paper.

Roodman, D. (2009). How to do xtabond2: An introduction to difference and system GMM in Stata. Stata Journal 9, 86-136.

Sapienza, P. (2004). The effects of government ownership on bank lending. Journal of Financial Economics 72(2), 357-384.

Vernikov, A. (2017). A guide to Russian bank data: breaking down the sample of banks. Available at SSRN: http://ssrn.com/abstract $=2600738$.

Windmeijer, F. (2005). A finite sample correction for the variance of linear efficient twostep GMM estimators. Journal of Econometrics 126, 25-51. 
Table 1.

Descriptive statistics of the main variables

Panel A of this table provides the descriptive statistics for the main variables included in the estimations. Panel B presents the difference in averages of key variables across bank types. The difference is tested with t-tests, which are provided in parenthesis. ${ }^{*}, * *$, and $* * *$ denote an estimate significantly different from 0 at the $10 \%, 5 \%$, and $1 \%$ levels, respectively. All variables follow the Table A1 definitions.

\section{Panel A}

\begin{tabular}{lcrrrrr}
\hline & $\mathrm{N}$ & Mean & Median & \multicolumn{1}{l}{ SD } & \multicolumn{1}{c}{ Min } & Max \\
\hline$\Delta$ Liquidity creation (cat) & 36121 & 0.25 & 0.13 & 1.29 & -5.08 & 7.28 \\
$\Delta$ Liquidity creation (mat) & 34219 & -0.15 & -0.03 & 1.48 & -6.06 & 4.35 \\
GDP growth & 44227 & 0.17 & 0.20 & 0.11 & -0.10 & 0.36 \\
High GDP growth & 44227 & 0.15 & 0.20 & 0.12 & 0 & 0.36 \\
Low GDP growth & 44227 & 0.01 & 0.00 & 0.04 & -0.10 & 0.16 \\
Credit growth & 35152 & 0.28 & 0.19 & 0.47 & -0.60 & 2.63 \\
Real investments growth (RIG) & 44227 & 0.18 & 0.18 & 0.16 & -0.14 & 0.51 \\
Lagged Log(assets) & 41760 & 14.61 & 14.49 & 2.00 & 6.78 & 23.84 \\
Lagged Equity/Assets & 41760 & 0.22 & 0.17 & 0.17 & -0.68 & 1.00 \\
Lagged Overdue loans/Loans & 40796 & 0.03 & 0.01 & 0.06 & 0.00 & 1.00 \\
Lagged Loans/Assets & 41760 & 0.57 & 0.62 & 0.21 & 0.00 & 0.98 \\
State-owned & 44222 & 0.05 & 0.00 & 0.21 & 0.00 & 1.00 \\
Foreign & 44222 & 0.09 & 0.00 & 0.29 & 0.00 & 1.00 \\
\hline
\end{tabular}

Panel B

\begin{tabular}{lcccccc}
\hline & & & \multicolumn{4}{c}{ Difference in means } \\
\hline & \multirow{2}{*}{ State-owned } & Foreign & Private & $\begin{array}{c}\text { State vs. } \\
\text { Private }\end{array}$ & $\begin{array}{c}\text { Foreign } \\
\text { vs. Private }\end{array}$ & $\begin{array}{c}\text { State vs. } \\
\text { Foreign }\end{array}$ \\
\hline$\Delta$ Liquidity creation (cat) & 0.23 & 0.28 & 0.25 & -0.01 & 0.03 & -0.05 \\
& & & & $(0.45)$ & $(1.32)$ & $(1.21)$ \\
Credit growth & 0.25 & \multirow{2}{*}{0.29} & 0.28 & $-0.03^{* *}$ & $0.01^{*}$ & $-0.04^{* * *}$ \\
& & & & $(2.03)$ & $(1.40)$ & $(2.42)$ \\
\hline
\end{tabular}


Table 2.

\section{Liquidity creation measures}

This table classifies all balance sheet items in terms of their liquidity. The weight of each category is given in parentheses and it is used to calculate two liquidity creation measures following Equation (1). Category Measure denotes a category-based liquidity creation measure, whereby bank activities are classified based on various categories. Maturity Measure is a maturity-based liquidity creation measure that is based on category, maturity classification for interbank loans, and total liabilities.

\begin{tabular}{|c|c|c|c|}
\hline \multirow{8}{*}{ 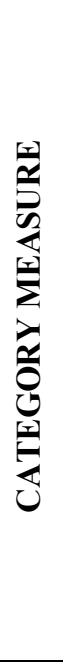 } & Illiquid assets $(1 / 2)$ & Semi-liquid assets (0) & Liquid assets $(-1 / 2)$ \\
\hline & Corporate loans & Interbank loans & Cash \\
\hline & Other assets & Loans to government & $\begin{array}{c}\text { Correspondent accounts with other } \\
\text { banks }\end{array}$ \\
\hline & & Loans to individuals & $\begin{array}{l}\text { Total securities (stocks, debt } \\
\text { securities, promissory notes) }\end{array}$ \\
\hline & Liquid liabilities (1/2) & Semi-liquid liabilities (0) & $\begin{array}{l}\text { Illiquid liabilities and capital } \\
\qquad(-1 / 2)\end{array}$ \\
\hline & $\begin{array}{l}\text { Debt securities issued } \\
\text { (bonds and promissory } \\
\text { notes) }\end{array}$ & $\begin{array}{c}\text { Debt securities issued } \\
\text { (deposit and saving } \\
\text { certificates) }\end{array}$ & Other liabilities \\
\hline & $\begin{array}{l}\text { Claims of non-bank sector: } \\
\text { settlement accounts (firms, } \\
\text { households, government) }\end{array}$ & $\begin{array}{l}\text { Claims of non-bank sector: } \\
\text { term and other deposits } \\
\text { (firms, households, } \\
\text { government) }\end{array}$ & Capital \\
\hline & Claims of banks & & \\
\hline \multirow{11}{*}{ 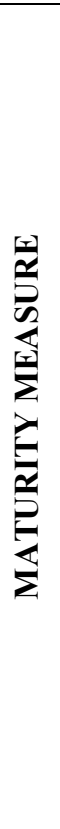 } & Illiquid assets (1/2) & Semi-liquid assets (0) & Liquid assets $(-1 / 2)$ \\
\hline & $\begin{array}{c}\text { Corporate loans (maturity } \\
\text { over } 1 \text { year) }\end{array}$ & $\begin{array}{c}\text { Corporate loans (maturity } \\
\text { less than } 1 \text { year) }\end{array}$ & Cash \\
\hline & $\begin{array}{l}\text { Loans to government } \\
\text { (maturity over } 1 \text { year) }\end{array}$ & $\begin{array}{c}\text { Loans to government } \\
\text { (maturity less than } 1 \text { year) }\end{array}$ & $\begin{array}{l}\text { Correspondent accounts with other } \\
\text { banks }\end{array}$ \\
\hline & $\begin{array}{l}\text { Loans to individuals } \\
\text { (maturity over } 1 \text { year) }\end{array}$ & $\begin{array}{c}\text { Loans to individuals } \\
\text { (maturity less than } 1 \text { year) }\end{array}$ & $\begin{array}{l}\text { Total securities (stocks, debt } \\
\text { securities, promissory notes) }\end{array}$ \\
\hline & $\begin{array}{l}\text { Loans to banks (maturity } \\
\text { over } 1 \text { year) }\end{array}$ & $\begin{array}{c}\text { Loans to banks (maturity less } \\
\text { than } 1 \text { year) }\end{array}$ & \\
\hline & Other loans & & \\
\hline & Other assets & & \\
\hline & Liquid liabilities (1/2) & Semi-liquid liabilities (0) & $\begin{array}{c}\text { Illiquid liabilities and capital } \\
(-1 / 2)\end{array}$ \\
\hline & $\begin{array}{l}\text { Debt securities issued } \\
\text { (bonds and promissory } \\
\text { notes) }\end{array}$ & $\begin{array}{c}\text { Debt securities issued } \\
\text { (deposit and saving } \\
\text { certificates) }\end{array}$ & $\begin{array}{l}\text { Deposits (maturity over } 1 \text { year and } \\
\text { uncertain term to maturity) }\end{array}$ \\
\hline & $\begin{array}{l}\text { Claims of non-bank sector: } \\
\text { settlement accounts (firms, } \\
\text { households, government) }\end{array}$ & $\begin{array}{c}\text { Deposits } \\
\text { (maturity less than } 1 \text { year) }\end{array}$ & Other liabilities \\
\hline & Claims of banks & & Capital \\
\hline
\end{tabular}


Table 3.

Main estimations

The dependent variable is the growth in liquidity creation based on category. Regression type (OLS with fixed effects or System GMM) indicated at the top of each column. All variables are defined as in Table A1. Robust standard errors in parentheses. ${ }^{*}, * *$, and $* * *$ denote an estimate significantly different from 0 at the $10 \%, 5 \%$, and $1 \%$ levels, respectively.

\begin{tabular}{|c|c|c|c|c|}
\hline & \multicolumn{4}{|c|}{ Dependent variable $=\Delta$ liquidity creation $(\mathrm{CAT})$} \\
\hline & $(1)$ & $(2)$ & (3) & $(4)$ \\
\hline Regression type & OLS with FE & Sys. GMM & OLS with FE & Sys. GMM \\
\hline GDP growth & $\begin{array}{l}0.711 * * * \\
(0.16)\end{array}$ & $\begin{array}{l}0.571 * * * \\
(0.13)\end{array}$ & $\begin{array}{l}0.719 * * * \\
(0.16)\end{array}$ & $\begin{array}{l}0.505^{* * *} \\
(0.15)\end{array}$ \\
\hline $\begin{array}{l}\text { Lagged } \Delta \text { Liquidity creation } \\
\text { (cat) }\end{array}$ & & $\begin{array}{l}0.430^{* * *} \\
(0.02)\end{array}$ & & $\begin{array}{l}0.430^{* * *} \\
(0.02)\end{array}$ \\
\hline State-owned & & & $\begin{array}{l}-0.018 \\
(0.13)\end{array}$ & $\begin{array}{l}-0.056 \\
(0.07)\end{array}$ \\
\hline State-owned x GDP growth & & & $\begin{array}{l}0.230 \\
(0.28)\end{array}$ & $\begin{array}{l}0.142 \\
(0.19)\end{array}$ \\
\hline Foreign & & & $\begin{array}{l}-0.066 \\
(0.15)\end{array}$ & $\begin{array}{l}0.053 \\
(0.10)\end{array}$ \\
\hline Foreign $\mathrm{x}$ GDP growth & & & $\begin{array}{l}-0.253 \\
(0.43)\end{array}$ & $\begin{array}{l}-0.327 \\
(0.29)\end{array}$ \\
\hline Lagged Log(assets) & $\begin{array}{l}-0.003 \\
(0.03)\end{array}$ & $\begin{array}{l}-0.089 * * * \\
(0.03)\end{array}$ & $\begin{array}{l}-0.002 \\
(0.03)\end{array}$ & $\begin{array}{l}-0.041 \\
(0.04)\end{array}$ \\
\hline Lagged Equity/Assets & $\begin{array}{l}-0.904^{* * *} \\
(0.15)\end{array}$ & $\begin{array}{l}-1.501^{* * *} \\
(0.32)\end{array}$ & $\begin{array}{l}-0.902^{* * *} \\
(0.15)\end{array}$ & $\begin{array}{l}-1.675^{* * *} \\
(0.32)\end{array}$ \\
\hline Lagged Overdue Loans/Loans & $\begin{array}{l}-1.468^{* * *} \\
(0.31)\end{array}$ & $\begin{array}{l}-1.732^{* * *} \\
(0.43)\end{array}$ & $\begin{array}{l}-1.469^{* * *} \\
(0.31)\end{array}$ & $\begin{array}{l}-1.355^{* * *} \\
(0.41)\end{array}$ \\
\hline Lagged Loans/Assets & $\begin{array}{l}1.154 * * * \\
(0.11)\end{array}$ & $\begin{array}{l}1.441 * * * \\
(0.18)\end{array}$ & $\begin{array}{l}1.157 * * * \\
(0.11)\end{array}$ & $\begin{array}{l}1.503 * * * \\
(0.19)\end{array}$ \\
\hline Constant & $\begin{array}{l}-0.045 \\
(0.45) \\
\end{array}$ & $\begin{array}{l}0.796 \\
(0.51) \\
\end{array}$ & $\begin{array}{l}-0.059 \\
(0.45) \\
\end{array}$ & $\begin{array}{l}0.158 \\
(0.58)\end{array}$ \\
\hline No. of obs. & 35349 & 33099 & 35347 & 33097 \\
\hline Adjusted R-squared & 0.044 & & 0.044 & \\
\hline Number of banks & 1180 & 1167 & 1180 & 1167 \\
\hline Number of instruments & & 720 & & 740 \\
\hline $\operatorname{AR}(2)$ test $p$-value & & 0.195 & & 0.206 \\
\hline Hansen OIR test $\mathrm{p}$-value & & 0.118 & & 0.298 \\
\hline
\end{tabular}


Table 4.

\section{High and low GDP growth}

The dependent variable is the growth in liquidity creation based on category measure. Regression type (OLS with fixed effects or System GMM) indicated at the top of each column. High and Low GDP growth are defined using the value of average GDP per capita growth over the full sample period. High (Low) GDP growth is equal to the actual GDP per capita growth if above (below) the mean, and zero otherwise. Other variables follow the Table A1 definitions. Robust standard errors in parentheses. *, **, and *** denote an estimate significantly different from 0 at the $10 \%, 5 \%$, and $1 \%$ levels, respectively.

\begin{tabular}{lll}
\hline & \multicolumn{2}{c}{ Dependent variable $=\Delta$ Liquidity } \\
creation $(\mathrm{CAT})$
\end{tabular}


Table 5.

\section{Alternative liquidity creation measure}

The dependent variable is the growth in liquidity creation based on maturity. Regression type (OLS with fixed effects or System GMM) indicated at the top of each column. All variables follow the Table A1 definitions. Robust standard errors in parentheses. ${ }^{*}, * *$, and $* * *$ denote an estimate significantly different from 0 at the $10 \%, 5 \%$, and $1 \%$ levels, respectively.

\begin{tabular}{|c|c|c|c|c|}
\hline & \multicolumn{4}{|c|}{ Dependent variable $=\Delta$ Liquidity creation $(\mathrm{MAT})$} \\
\hline & $(1)$ & $(2)$ & $(3)$ & $(4)$ \\
\hline Regression type & OLS with FE & Sys. GMM & OLS with FE & Sys. GMM \\
\hline GDP growth & $\begin{array}{l}0.356^{*} \\
(0.20)\end{array}$ & $\begin{array}{l}0.226 \\
(0.18)\end{array}$ & $\begin{array}{l}0.393 * \\
(0.20)\end{array}$ & $\begin{array}{l}0.441^{* *} \\
(0.20)\end{array}$ \\
\hline $\begin{array}{l}\text { Lagged } \Delta \text { Liquidity creation } \\
\text { (mat) }\end{array}$ & & $\begin{array}{l}0.271^{* * *} \\
(0.03)\end{array}$ & & $\begin{array}{l}0.293 * * * \\
(0.03)\end{array}$ \\
\hline State-owned & & & $\begin{array}{l}0.146 \\
(0.14)\end{array}$ & $\begin{array}{l}0.210^{*} \\
(0.11)\end{array}$ \\
\hline State-owned x GDP growth & & & $\begin{array}{l}0.195 \\
(0.43)\end{array}$ & $\begin{array}{l}0.357 \\
(0.30)\end{array}$ \\
\hline Foreign & & & $\begin{array}{l}0.080 \\
(0.16)\end{array}$ & $\begin{array}{l}0.208^{* *} \\
(0.09)\end{array}$ \\
\hline Foreign $x$ GDP growth & & & $\begin{array}{l}-0.615 \\
(0.53)\end{array}$ & $\begin{array}{l}-0.450 \\
(0.41)\end{array}$ \\
\hline Lagged Log(assets) & $\begin{array}{l}-0.048 \\
(0.03)\end{array}$ & $\begin{array}{l}-0.102^{* * *} \\
(0.04)\end{array}$ & $\begin{array}{l}-0.049 \\
(0.03)\end{array}$ & $\begin{array}{l}-0.111^{* * *} \\
(0.04)\end{array}$ \\
\hline Lagged Equity/Assets & $\begin{array}{l}-0.350^{* *} \\
(0.16)\end{array}$ & $\begin{array}{l}-1.088^{* * *} \\
(0.34)\end{array}$ & $\begin{array}{l}-0.353^{* *} \\
(0.16)\end{array}$ & $\begin{array}{l}-0.804^{* * *} \\
(0.30)\end{array}$ \\
\hline Lagged Overdue Loans/Loans & $\begin{array}{l}0.096 \\
(0.26)\end{array}$ & $\begin{array}{l}-0.080 \\
(0.38)\end{array}$ & $\begin{array}{l}0.081 \\
(0.26)\end{array}$ & $\begin{array}{l}-0.282 \\
(0.36)\end{array}$ \\
\hline Lagged Loans/Assets & $\begin{array}{l}1.281 * * * \\
(0.11)\end{array}$ & $\begin{array}{l}1.662 * * * \\
(0.24)\end{array}$ & $\begin{array}{l}1.284 * * * \\
(0.11)\end{array}$ & $\begin{array}{l}1.578 * * * \\
(0.25)\end{array}$ \\
\hline Constant & $\begin{array}{l}-0.018 \\
(0.50) \\
\end{array}$ & $\begin{array}{l}0.662 \\
(0.54) \\
\end{array}$ & $\begin{array}{l}-0.014 \\
(0.49) \\
\end{array}$ & $\begin{array}{l}0.711 \\
(0.62)\end{array}$ \\
\hline No. of obs. & 33442 & 30142 & 33440 & 30140 \\
\hline Adjusted R-squared & 0.031 & & 0.031 & \\
\hline Number of banks & 1180 & 1167 & 1180 & 1167 \\
\hline Number of instruments & & 720 & & 740 \\
\hline $\operatorname{AR}(2)$ test $p$-value & & 0.162 & & 0.261 \\
\hline Hansen OIR test $\mathrm{p}$-value & & 0.405 & & 0.789 \\
\hline
\end{tabular}


Table 6.

Alternative indicator of the business cycle

The dependent variable is the growth in liquidity creation based on category measure. Regression type (OLS with fixed effects or System GMM) indicated at the top of each column. All variables follow the Table A1 definitions. Robust standard errors in parentheses. *, **, and *** denote an estimate significantly different from 0 at the $10 \%, 5 \%$, and $1 \%$ levels, respectively.

\begin{tabular}{|c|c|c|c|c|}
\hline & \multicolumn{4}{|c|}{ Dependent variable $=\Delta$ Liquidity creation $(\mathrm{CAT})$} \\
\hline & $(1)$ & $(2)$ & (3) & $(4)$ \\
\hline Regression type & OLS with FE & Sys. GMM & OLS with FE & Sys. GMM \\
\hline Real investments growth (RIG) & $\begin{array}{l}0.798 * * * \\
(0.12)\end{array}$ & $\begin{array}{l}0.570^{* * *} \\
(0.09)\end{array}$ & $\begin{array}{l}0.788^{* * * *} \\
(0.12)\end{array}$ & $\begin{array}{l}0.521^{* * *} \\
(0.11)\end{array}$ \\
\hline $\begin{array}{l}\text { Lagged } \Delta \text { Liquidity creation } \\
\text { (cat) }\end{array}$ & & $\begin{array}{l}0.420^{* * *} \\
(0.02)\end{array}$ & & $\begin{array}{l}0.425^{* * *} \\
(0.02)\end{array}$ \\
\hline State-owned & & & $\begin{array}{l}-0.003 \\
(0.13)\end{array}$ & $\begin{array}{l}-0.057 \\
(0.08)\end{array}$ \\
\hline State-owned x RIG & & & $\begin{array}{l}0.147 \\
(0.21)\end{array}$ & $\begin{array}{l}0.117 \\
(0.15)\end{array}$ \\
\hline Foreign & & & $\begin{array}{l}-0.111 \\
(0.15)\end{array}$ & $\begin{array}{l}0.012 \\
(0.09)\end{array}$ \\
\hline Foreign $x$ RIG & & & $\begin{array}{l}0.060 \\
(0.33)\end{array}$ & $\begin{array}{l}-0.039 \\
(0.22)\end{array}$ \\
\hline Lagged Log(assets) & $\begin{array}{l}-0.007 \\
(0.03)\end{array}$ & $\begin{array}{l}-0.097 * * * \\
(0.03)\end{array}$ & $\begin{array}{l}-0.005 \\
(0.03)\end{array}$ & $\begin{array}{l}-0.044 \\
(0.04)\end{array}$ \\
\hline Lagged Equity/Assets & $\begin{array}{l}-0.910^{* * *} \\
(0.15)\end{array}$ & $\begin{array}{l}-1.528^{* * *} \\
(0.34)\end{array}$ & $\begin{array}{l}-0.908^{* * *} \\
(0.15)\end{array}$ & $\begin{array}{l}-1.746^{* * *} \\
(0.33)\end{array}$ \\
\hline Lagged Overdue Loans/Loans & $\begin{array}{l}-1.474 * * * \\
(0.31)\end{array}$ & $\begin{array}{l}-1.785^{* * *} \\
(0.41)\end{array}$ & $\begin{array}{l}-1.473^{* * *} \\
(0.31)\end{array}$ & $\begin{array}{l}-1.494 * * * \\
(0.42)\end{array}$ \\
\hline Lagged Loans/Assets & $\begin{array}{l}1.158^{* * *} \\
(0.11)\end{array}$ & $\begin{array}{l}1.508 \\
(0.13)\end{array}$ & $\begin{array}{l}1.161^{* * *} \\
(0.11)\end{array}$ & $\begin{array}{l}1.532 * * * \\
(0.20)\end{array}$ \\
\hline Constant & $\begin{array}{l}-0.000 \\
(0.44)\end{array}$ & $\begin{array}{l}0.872 * \\
(0.50)\end{array}$ & $\begin{array}{l}-0.020 \\
(0.45)\end{array}$ & $\begin{array}{l}0.198 \\
(0.55)\end{array}$ \\
\hline No. of obs. & 35349 & 33099 & 35347 & 33097 \\
\hline Adjusted R-squared & 0.045 & & 0.045 & \\
\hline Number of banks & 1180 & 1167 & 1180 & 1167 \\
\hline Number of instruments & & 720 & & 740 \\
\hline $\mathrm{AR}(2)$ test $p$-value & & 0.239 & & 0.229 \\
\hline Hansen OIR test p-value & & 0.158 & & 0.368 \\
\hline
\end{tabular}


Table 7.

\section{Cyclicality of bank liquidity creation by bank size}

The table reports the estimation results for different bank size categories. The dependent variable is the growth in liquidity creation based on category measure. Columns 1 and 3 are for the largest 50 banks, Columns 2 and 4 are for the next 150 large banks, and Columns 3 and 6 include all other banks. Regression type (OLS with fixed effects in all cases here) indicated at the top of each column. All variables follow the Table A1 definitions. Robust standard errors in parentheses. *, **, and *** denote an estimate significantly different from 0 at the $10 \%, 5 \%$, and $1 \%$ levels, respectively.

\begin{tabular}{|c|c|c|c|c|c|c|}
\hline & \multicolumn{6}{|c|}{ Dependent variable $=\Delta$ liquidity creation $(\mathrm{CAT})$} \\
\hline & $(1)$ & $(2)$ & (3) & $(4)$ & $(5)$ & (6) \\
\hline Regression type & $\begin{array}{l}\text { OLS } \\
\text { with FE }\end{array}$ & $\begin{array}{l}\text { OLS with } \\
\text { FE }\end{array}$ & $\begin{array}{l}\text { OLS with } \\
\text { FE }\end{array}$ & $\begin{array}{c}\text { OLS } \\
\text { with FE }\end{array}$ & $\begin{array}{l}\text { OLS with } \\
\text { FE }\end{array}$ & $\begin{array}{l}\text { OLS with } \\
\text { FE }\end{array}$ \\
\hline & Top 50 & Next 150 & Rest & Top 50 & Next 150 & Rest \\
\hline GDP growth & $\begin{array}{l}1.016^{* * *} \\
(0.343)\end{array}$ & $\begin{array}{l}0.728^{* *} \\
(0.340)\end{array}$ & $\begin{array}{l}0.691 * * * \\
(0.189)\end{array}$ & $\begin{array}{l}0.962^{*} \\
(0.519)\end{array}$ & $\begin{array}{l}0.780^{* *} \\
(0.362)\end{array}$ & $\begin{array}{l}0.708^{* * * *} \\
(0.190)\end{array}$ \\
\hline State-owned & & & & $\begin{array}{l}-0.112 \\
(0.261)\end{array}$ & $\begin{array}{l}-0.006 \\
(0.241)\end{array}$ & $\begin{array}{l}0.009 \\
(0.178)\end{array}$ \\
\hline $\begin{array}{l}\text { State-owned x GDP } \\
\text { growth }\end{array}$ & & & & $\begin{array}{l}-0.229 \\
(0.760)\end{array}$ & $\begin{array}{l}0.073 \\
(0.789)\end{array}$ & $\begin{array}{l}0.313 \\
(0.333)\end{array}$ \\
\hline Foreign & & & & $\begin{array}{l}-0.252 \\
(0.199)\end{array}$ & $\begin{array}{l}0.025 \\
(0.284)\end{array}$ & $\begin{array}{l}0.120 \\
(0.235)\end{array}$ \\
\hline Foreign $x$ GDP growth & & & & $\begin{array}{l}0.314 \\
(0.620)\end{array}$ & $\begin{array}{l}-0.361 \\
(0.605)\end{array}$ & $\begin{array}{l}-0.745 \\
(0.784)\end{array}$ \\
\hline Lagged Log(assets) & $\begin{array}{l}-0.196 \\
(0.119)\end{array}$ & $\begin{array}{l}-0.151^{*} \\
(0.082)\end{array}$ & $\begin{array}{l}0.039 \\
(0.035)\end{array}$ & $\begin{array}{l}-0.196 \\
(0.120)\end{array}$ & $\begin{array}{l}-0.151^{*} \\
(0.083)\end{array}$ & $\begin{array}{l}0.038 \\
(0.035)\end{array}$ \\
\hline Lagged Equity/Assets & $\begin{array}{l}-2.775^{*} \\
(1.503)\end{array}$ & $\begin{array}{l}-1.115 \\
(0.715)\end{array}$ & $\begin{array}{l}-0.846 * * * \\
(0.157)\end{array}$ & $\begin{array}{l}-2.762^{*} \\
(1.493)\end{array}$ & $\begin{array}{l}-1.109 \\
(0.715)\end{array}$ & $\begin{array}{l}-0.847 * * * \\
(0.158)\end{array}$ \\
\hline Lagged Overdue & & & & & & \\
\hline Loans/Loans & $\begin{array}{l}-2.217 \\
(1.646)\end{array}$ & $\begin{array}{l}-1.807 * * \\
(0.715)\end{array}$ & $\begin{array}{l}-1.359^{* * *} \\
(0.342)\end{array}$ & $\begin{array}{l}-2.214 \\
(1.600)\end{array}$ & $\begin{array}{l}-1.798^{* *} \\
(0.710)\end{array}$ & $\begin{array}{l}-1.371 * * * \\
(0.343)\end{array}$ \\
\hline Lagged Loans/Assets & $\begin{array}{l}0.574 \\
(0.604)\end{array}$ & $\begin{array}{l}0.679 * * \\
(0.337)\end{array}$ & $\begin{array}{l}1.226^{* * *} \\
(0.118)\end{array}$ & $\begin{array}{l}0.629 \\
(0.655)\end{array}$ & $\begin{array}{l}0.681 * * \\
(0.337)\end{array}$ & $\begin{array}{l}1.226^{* * *} \\
(0.118)\end{array}$ \\
\hline Constant & $\begin{array}{l}3.749 * \\
(2.192)\end{array}$ & $\begin{array}{l}2.687^{*} \\
(1.405)\end{array}$ & $\begin{array}{l}-0.655 \\
(0.485) \\
\end{array}$ & $\begin{array}{l}3.780 * \\
(2.235)\end{array}$ & $\begin{array}{l}2.676^{*} \\
(1.412)\end{array}$ & $\begin{array}{l}-0.647 \\
(0.484) \\
\end{array}$ \\
\hline No. of obs. & 1834 & 5076 & 28439 & 1834 & 5076 & 28437 \\
\hline Adjusted R-squared & 0.109 & 0.067 & 0.042 & 0.112 & 0.068 & 0.042 \\
\hline Number of banks & 50 & 150 & 980 & 50 & 150 & 980 \\
\hline
\end{tabular}


Table 8.

\section{Cyclicality of bank lending}

The dependent variable is the growth in bank lending. Regression type (OLS with fixed effects in all cases here) indicated at the top of each column. All variables follow the definitions in Tables A1 and 4. Robust standard errors in parentheses. $*, * *$, and $* * *$ denote an estimate significantly different from 0 at the $10 \%$, $5 \%$, and $1 \%$ levels, respectively.

\begin{tabular}{|c|c|c|c|}
\hline & \multicolumn{3}{|c|}{ Dependent variable $=\Delta$ loans } \\
\hline & (1) & $(2)$ & (3) \\
\hline Regression type & OLS with FE & OLS with FE & OLS with FE \\
\hline GDP growth & $\begin{array}{l}0.433 * * * \\
(0.05)\end{array}$ & $\begin{array}{l}0.405^{* * *} \\
(0.05)\end{array}$ & \\
\hline High GDP growth & & & $\begin{array}{l}0.162 * * * \\
(0.04)\end{array}$ \\
\hline Low GDP growth & & & $\begin{array}{l}-0.296^{* * *} \\
(0.07)\end{array}$ \\
\hline State-owned & & $\begin{array}{l}-0.068 \\
(0.07)\end{array}$ & $\begin{array}{l}-0.056 \\
(0.08)\end{array}$ \\
\hline State-owned x GDP growth & & $\begin{array}{l}0.165 \\
(0.13)\end{array}$ & \\
\hline Foreign & & $\begin{array}{l}-0.106 \\
(0.07)\end{array}$ & $\begin{array}{l}-0.103 \\
(0.06)\end{array}$ \\
\hline Foreign $\mathrm{x}$ GDP growth & & $\begin{array}{l}0.300^{*} \\
(0.17)\end{array}$ & \\
\hline State-owned $x$ High GDP growth & & & $\begin{array}{l}0.177 \\
(0.16)\end{array}$ \\
\hline State-owned $x$ Low GDP growth & & & $\begin{array}{l}0.762^{*} \\
(0.44)\end{array}$ \\
\hline Foreign x High GDP growth & & & $\begin{array}{l}0.347^{* *} \\
(0.16)\end{array}$ \\
\hline Foreign $x$ Low GDP growth & & & $\begin{array}{l}-0.080 \\
(0.30)\end{array}$ \\
\hline Lagged Log(assets) & $\begin{array}{l}0.023 * \\
(0.01)\end{array}$ & $\begin{array}{l}0.025^{*} \\
(0.01)\end{array}$ & $\begin{array}{l}0.025 * \\
(0.01)\end{array}$ \\
\hline Lagged Equity/Assets & $\begin{array}{l}-0.182^{* * *} \\
(0.08)\end{array}$ & $\begin{array}{l}-0.182 * * \\
(0.08)\end{array}$ & $\begin{array}{l}-0.179 * * \\
(0.08)\end{array}$ \\
\hline Lagged Overdue Loans/Loans & $\begin{array}{l}-2.277 * * * \\
(0.26)\end{array}$ & $\begin{array}{l}-2.267 * * * \\
(0.26)\end{array}$ & $\begin{array}{l}-2.258 * * * \\
(0.26)\end{array}$ \\
\hline Lagged Loans/Assets & $\begin{array}{l}0.202 * * * \\
(0.04)\end{array}$ & $\begin{array}{l}0.203 * * * \\
(0.04)\end{array}$ & $\begin{array}{l}0.205 * * * \\
(0.04)\end{array}$ \\
\hline Constant & $\begin{array}{l}-0.023 \\
(0.20) \\
\end{array}$ & $\begin{array}{l}-0.036 \\
(0.20) \\
\end{array}$ & $\begin{array}{l}0.016 \\
(0.20) \\
\end{array}$ \\
\hline No. of obs. & 35149 & 35147 & 35147 \\
\hline Adjusted R-squared & 0.148 & 0.149 & 0.149 \\
\hline Number of banks & 1162 & 1162 & 1162 \\
\hline
\end{tabular}


Table A1.

Definition of variables

\begin{tabular}{|c|c|}
\hline Variable & Definition \\
\hline$\Delta$ Liquidity creation (cat) & $\begin{array}{l}\text { Change in liquidity creation measure based on category } \\
\text { calculated by dividing quarterly observations in year } t \text { by the } \\
\text { same quarter in year } t-1 \text {. }\end{array}$ \\
\hline$\Delta$ Liquidity creation (mat) & $\begin{array}{l}\text { Change in liquidity creation measure based on maturity } \\
\text { calculated by dividing quarterly observations in year } t \text { by the } \\
\text { same quarter in year } t-1 \text {. }\end{array}$ \\
\hline GDP growth & $\begin{array}{l}\text { Change in GDP per capita by dividing quarterly observations in } \\
\text { year } t \text { by the same quarter in year } t-1 \text {. }\end{array}$ \\
\hline Credit growth & $\begin{array}{l}\text { Change in net loans to individuals and firms calculated by } \\
\text { dividing quarterly observations in year } t \text { by the same quarter in } \\
\text { year } t-1 \text {. }\end{array}$ \\
\hline $\begin{array}{l}\text { Real investments growth } \\
\text { (RIG) }\end{array}$ & $\begin{array}{l}\text { Change in real investments calculated by dividing quarterly } \\
\text { observations in year } t \text { by the same quarter in year } t-1 \text {. }\end{array}$ \\
\hline Lagged Log(assets) & Logarithm of total assets lagged by one quarter. \\
\hline Lagged Equity/Assets & $\begin{array}{l}\text { Book value of total-equity-to-total-assets ratio lagged by one } \\
\text { quarter. }\end{array}$ \\
\hline $\begin{array}{l}\text { Lagged Overdue } \\
\text { loans/Loans }\end{array}$ & $\begin{array}{l}\text { Nonperforming loans to total gross total loans lagged by one } \\
\text { quarter. }\end{array}$ \\
\hline Lagged Loans/Assets & Total-loans-to-total-assets ratio lagged by one quarter. \\
\hline State-owned & $\begin{array}{l}\text { Dummy variable equals one if majority stake of bank's equity is } \\
\text { owned by the federal government, central bank, state-owned } \\
\text { companies, or regional governments and municipalities, zero } \\
\text { otherwise. }\end{array}$ \\
\hline Foreign & $\begin{array}{l}\text { Dummy variable equals one if foreign ownership corresponds to } \\
\text { at least a } 50 \% \text { share, zero otherwise. }\end{array}$ \\
\hline High GDP growth & Actual GDP per capita growth if above the mean, zero otherwise. \\
\hline Low GDP growth & Actual GDP per capita growth if below the mean, zero otherwise. \\
\hline
\end{tabular}

